\title{
Basque Genitive Case and Multiple Checking*
}

\author{
XABIER ARTIAGOITIA \\ Universidad del País Vasco / Euskal Herriko Unibertsitatea
}

\section{Introduction}

In this article I propose (a) that Basque genitive structural case is checked in the functional projection possessive (or possessor as proposed by De Wit (1997) and others based on pioneering work by Szabolcsi); and (b) that this functional projection allows both subject and object to check case simultaneously in a multiple specifier configuration. The diagram in (1) illustrates the core of the proposal:
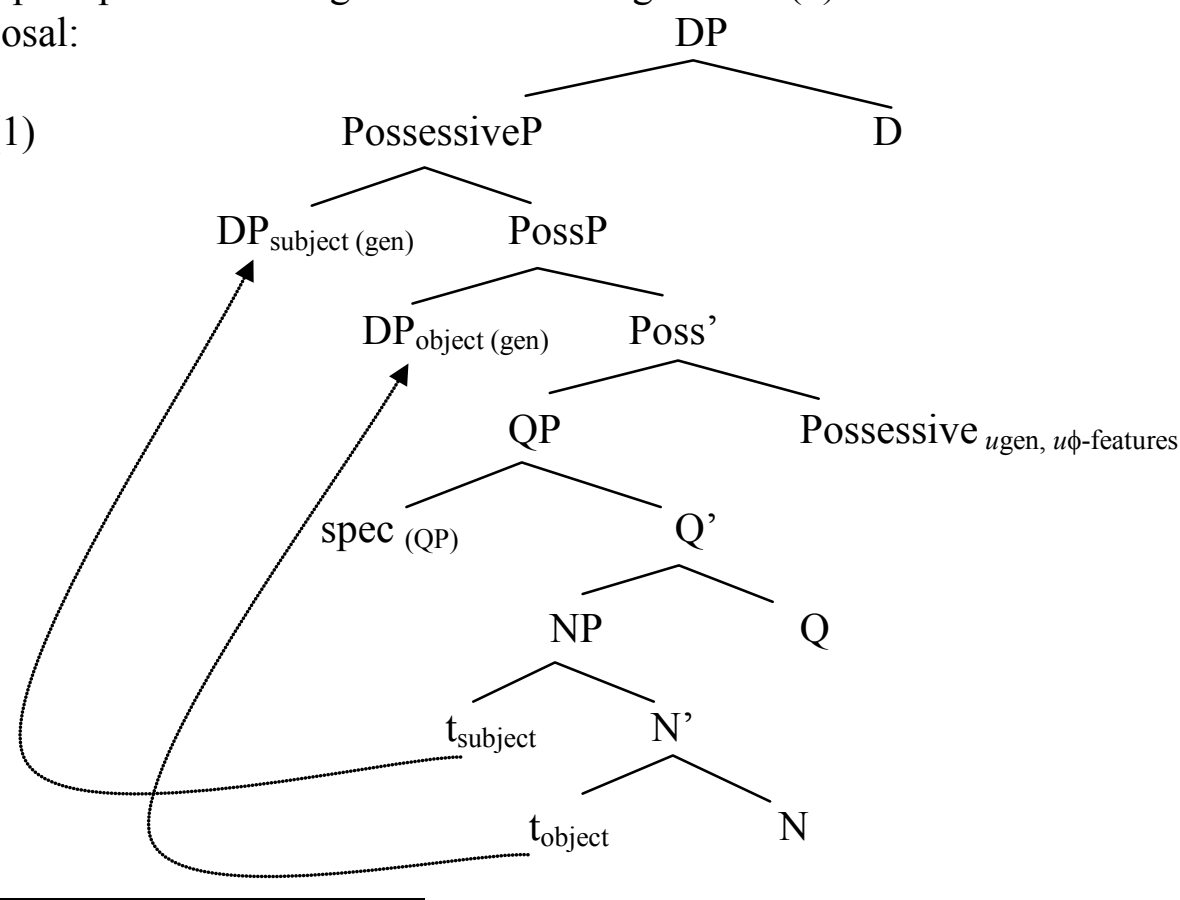

\footnotetext{
* This research is supported by grant FFI2008-05135/FILO from the Spanish Ministry for Science and Innovation. I use the following abbreviations: art = article, aux = auxiliary, A = absolutive, D $=$ dative, $\mathrm{E}=$ ergative, gen = genitive, $\mathrm{P}=$ possessor, $\mathrm{pl}=$ plural(izer), $\mathrm{R}=$ root. When irrelevant for the discussion, I simply gloss the auxiliary verb as "aux".
} 


\section{Xabier Artiagoitia}

This instance of multiple genitive case bears on the correct characterization of the Person Case Constraint and on the characterization of the operation Agree; the Basque data presented favors Jeong's formulation of the constraint in (2):

\section{(2) General Person-Case Constraint}

Two DPs cannot be $[+$ person $] /[+$ animate $]$ if they check that feature against the same functional head (T/v) (Jeong 2004: 419).

I will argue that the functional head possessive in Basque allows more than one DP to check genitive case, but only one of them can be [+ person]. Therefore, the head possessive should be added to $\mathrm{T} / \mathrm{v}$ in (2).

I have structured the article as follows: after a short introduction to Basque genitive DPs in section 1, section 2 makes a first sketch of the proposal. Section 3 develops it further and presents arguments for DPs' raising past QP in Basque to check genitive case in a multiple specifier possessive-phrase; I discuss superiority phenomena, together with PCC effects, as evidence for multiple checking.

\section{A Descriptive Outline of Basque DPs and Genitives}

My departing assumption is that the structure of Basque DPs looks like (3):

(3) $[\mathrm{DP}[$ PossP [QP XP [Q' [NP] Q]] Poss] D] where $[\mathrm{XP}=\mathrm{QPs}$, including numerals, and measure phrases]

The head possessive, the subject matter of this article, is a functional head with no morphological realization in Basque. I take it for granted that Artiagoitia's (2002) analysis of Basque quantifiers is on the right track, namely that prenominal quantifiers (including numerals, measure phrases, and heavier quantifiers like hainbat, hainbeste 'so many/much') occupy the specifier position of $\mathrm{Q}$ and that the head-like quantifiers occupy the $\mathrm{Q}$ position mediating between the Noun and the Determiner position. I provide illustrative examples in (4):
a. liburu (gutxi) hauek $=[\mathrm{DP}[\mathrm{QP}$ [NP liburu] [Q (gutxi)]] [D hauek]] book few these 'these (few) books'
b. hainbat liburu $=\left[\mathrm{DP}[\mathrm{QP}[\mathrm{QP}\right.$ hainbat $][\mathrm{NP}$ liburu $\left.][\mathrm{Q} \oslash]]\left[{ }_{\mathrm{D}} \oslash\right]\right]$ so many book 'so many books'
c. bost liburu(-ak) $=[\mathrm{DP}[\mathrm{QP}[\mathrm{QP}$ bost $][\mathrm{NP}$ liburu $]][\mathrm{D}(-\mathrm{ak})]]$
five book art (the) five books' 


\title{
Basque Genitive Case and Multiple Checking
}

\author{
d. gela bete liburu $\quad=\left[\mathrm{DP}\left[\mathrm{QP}[\mathrm{XP}\right.\right.$ gela bete $][\mathrm{NP}$ liburu $\left.]\left[{ }_{\mathrm{D}} Ø\right]\right]$ \\ room full book \\ 'a room full of books'
}

The main features of Basque genitive DPs in comparison with other wellknown languages are summarized in (5):

(5) a. Basque genitives are of the type $D P+$ case;

b. Basque genitives are not in complementary distribution with determiner heads;

c. there are not two types of DP genitives inside noun phrases.

Basque genitives are of the type DP + case. In other words, subject, object (and possessor) genitives are full DPs bearing the case mark -(r)en, the older form $-(r) e$ in the case of personal pronouns. Relevant examples are given in (6):

\begin{tabular}{|c|c|c|}
\hline $\begin{array}{l}\text { Etorri } \\
\text { come }\end{array}$ & $\begin{array}{l}\text { berri } \\
\text { just }\end{array}$ & $\begin{array}{l}\text { den } \\
\text { aux.comp }\end{array}$ \\
\hline
\end{tabular}
'the man who has just arrived's brother'

$\begin{array}{lllll}\text { b. Artista hor-ren } & \text { Miren-en } & \text { eta } & \text { ni-re } & \text { erretratua } \\ \text { artist that.gen } & \text { Mary.gen } & \text { and } & \text { I.gen } & \text { portrait.art } \\ \text { 'That artist's portrait of Mary and me' } & & & \end{array}$

Basque genitive is akin to a case mark borne by DP arguments. In fact, most Basque scholars assume that genitive $-(r) e n$ is just the nominal counterpart of clausal ergative or absolutive case. A fully argument-loaded CP/DP parallelism strongly favors this conclusion, as you can see in (7):
a. Goenaga- $k$
bere
azken a
artelan-ak- $\varnothing$ erakutsi
ditu. Goenaga.E his last artwork.art.A exhibit
aux 'Goenaga exhibited his last artworks'
b. Goenaga-ren
bere azken artelan-en
erakusketa
Goenaga.gen his last artwork.gen exhibition

'Goenaga's exhibition of his last artworks'

Basque genitives are not in complementary distribution with determiner heads. This simply means that Basque articles, demonstratives and quantifiers, prenominal or postnominal, are never in complementary distribution with genitives, as it becomes evident upon looking at examples in (8):
a. $\{$ Atxagaren/ nire $\}$ liburu $\{-\mathrm{a}, \mathrm{hau}\}$

Atxaga's I.gen book art this 


\section{Xabier Artiagoitia}

' $\{$ the, this $\}$ book of mine/Atxaga's\}' (several interpretations)

b. $\{$ Atxagaren/nire $\}$ liburu $\{$ bat, batzuk\}

Atxaga's I.gen book one several

'one, several book(s) \{of mine/Atxaga's\}' (idem)

c. $\{$ Atxagaren/nire $\}$ hainbat liburu

Atxaga's I.gen so many book

'so many books \{of mine/Atxaga's\}'

(idem)

There aren't two types of DP genitives inside noun phrases. Basque doesn't have two different types of DP genitives (synthetic and periphrastic), and both subject and object genitives, as well as regular possessors, are isomorphic and equally prenominal, as can be seen in the examples (6)-(7b) and (8) above. The difference between the genitive and the so called locative genitive has a different source. I give a couple of examples of the locative genitive in (9):
a. Bilboko
itsas-museoa
.ko sea museum.art
'The sea museum in/from Bilbao'
b. zuretzako oparia you.for.ko gift.art 'a/the gift for you'

According to Goenaga (2003) and Artiagoitia (2006), there is a division of labor between-(r)en and -ko summarized in (10):

\section{(10) Basque DP-internal constituents}

a. DP arguments take genitive-(r)en;

b. Other constituents (PP, NP, QP, CP, AdvP...) take the genitive $-k o$

The division of labor between the two genitives reflects a category distinction (DP vs other categories) or, in the worst case, a category and selectional distinction (DP arguments vs other categories). The distinction is reminiscent of a DP's need of abstract case, and ultimately, of the Case Filter.

\section{Genitives Inside Noun Phrases: Basic Data}

The basic and most relevant piece of data is that a genitive usually precedes all other modifiers (except for relative clauses); it precedes $-k o$ modifiers and prenominal quantifiers:
a. Jonen
txistea
John.gen yesterday.ko joke.art
'John's joke from yesterday'
atzoko
b
b. Mirenen hiru autoak
Mary.gen three car.art
'Mary's three cars'




\section{Basque Genitive Case and Multiple Checking}

Let's focus on example (11b); it is worth noting that genitives are necessarily to the left of prenominal quantifiers like 'three' hiru or 'so much/many' hainbat as you can check in (12) and (13) respectively; this is so regardless of the interpretation of the genitive, as shown in example (13a) with a picture noun:
a. Mirenen hiru autoak $(=11 \mathrm{~b})$ Mary.gen three car.art 'Mary's three cars'
$\begin{array}{lll}\text { a. Jonen } & \text { hainbat } & \text { erretratu } \\ \text { John.gen } & \text { so-many } & \text { portrait }\end{array}$
John.gen so-many portrai
'so many portraits \{by, of John'
b. * hiru Mirenen autoak
b.* hainbat Jonen erretratu

Assuming that relational and derived nouns can have both subject and object arguments, examples like (12-13) suggest that DP arguments raise to some position higher than QP in Basque noun phrases.

The same is also true of normal possessors if these originate in some high position inside NP or a related projection as assumed by Longobardi (2001), Alexiadou et al. (2007), and others. So (14) reflects the derivation of (13a), which can be three-way ambiguous:

(14) $\left[\mathrm{DP} \ldots\right.$ Jonen $_{\mathrm{i}}\left[\mathrm{QP}\right.$ hainbat $\left[\mathrm{NP} \ldots \mathrm{t}_{\mathrm{i}} \ldots\right.$ erretratu $\left.] \ldots \mathrm{D}\right]$ (where $t_{i}=$ subject, object or possessor)

A similar raising analysis is required when both subject and object genitives co-occur in the same noun phrase; both subject and object must precede quantifiers (in 15a) and -ko phrases as well (e. g. in 15b):
a. Velazquezen
Felipe erregearen
bost erretratuak
gen king.gen
five portrait.art
'the five portraits of King Felipe by Velazquez'
b. Peruren Mirenen igerilekuko argazkia (Zabala 1999: 150)
Peter.gen Mary.gen pool.ko picture.art
'Peter's portrait of Mary at the swimming pool'

The derivation of the examples in (15) would be roughly as in (16):

(16) a. Velazquezen $n_{i}$ Felipe erregearen $n_{j}\left[Q P\right.$ bost $\left[{ }_{N P} t_{i} t_{j}\right.$ erretratu]]-ak

b. Peruren ${ }_{i}$ Mirenen $_{j}$ igerilekuko $\left[N P_{t_{i}} t_{j}\right.$ argazki]-a

The conclusion is, then, that subject and object genitives raise past QP (and past nominal adjuncts) in Basque DPs. The natural question is: do they move to the specifier of the same projection or do they move to different projections? 
In what follows, after further justifying the existence of a higher structural position for genitives, I provide positive evidence that all genitives raise to the specifier of the functional head possessive, thus creating a multiple-specifier configuration.

\section{Multiple Genitive Case: Justification and Development of the Proposal}

\subsection{Arguments for Locating Genitives above QP}

As the examples in (17) remind us, there is ample crosslinguistic evidence for a possessive-phrase on top of QP and below the DP projection, from a variety of languages and authors:
a. Catalan: les seves novelles de Nabokov the his novels of 'his novels of Nabokov'
$\begin{array}{llll}\text { b. Italian: il mio libro } & \\ & \text { the my book }\end{array}$ 'my book' (Picallo 1991: 284)

$\begin{array}{ll}\text { (a) Mari } & \text { kalap-ja-i } \\ \text { art Mari.nom } & \text { hat.agr.pl } \\ \text { 'Mary's hats' } & \end{array}$
d. Maorese: tā Hōne patu-nga o te
c. Hungarian: art .gen killing .gen art woman
'Hone's killing of the woman' (Pearce 1998: 427)
(Schoorlemmer 1998)
(Szabolcsi 1994: 180)
wahine

Seminal work by Szabolcsi is taken in the generative tradition as the main reference for proposing a functional projection right below DP connected with possessives; similar conclusions have been reached independently by many scholars, which may differ in the qualification of that functional projection: nominal inflection (Szabolcsi 1994 and related work); possessor (De Wit 1997, Delsing 1998, Schoolemmer 1998); Number (Picallo 1991); or just $A G R$ (Alexiadou et. al. 2007). Here, I call this projection possessive, slightly adapting De Wit's and Schlooemer's nomenclature.

Coming back to Basque, we have already seen the main argument for locating Basque genitives above QP: both subject and object arguments show up to the left of prenominal quantifiers, as sketched in (14) and (16) above. Furthermore, coordination data internal to Basque suggest that genitives and QP or NP form a constituent outside the scope of $\mathrm{D}$ (i.e. the article, demonstratives). The relevant examples are in (18): 


\section{Basque Genitive Case and Multiple Checking}

(18)

\begin{tabular}{|c|c|c|c|c|c|}
\hline $\begin{array}{r}\text { a. [[PossP Zure } \\
\text { you.ge }\end{array}$ & $\begin{array}{l}\text { liburu] } \\
\text { book }\end{array}$ & $\begin{array}{l}\text { ] eta [PossP } \\
\text { and }\end{array}$ & $\begin{array}{l}\text { nire } \\
\text { I.gen }\end{array}$ & $\begin{array}{l}\text { artikulu] } \\
\text { article }\end{array}$ & $\begin{array}{l}\text {-ak] } \\
\text { art }\end{array}$ \\
\hline \multicolumn{6}{|c|}{ 'the books of yours and articles of mine' } \\
\hline b. atzo & aipatu & zenituen [[Poss] & & zure & bi \\
\hline yesterday & mention & aux.comp & & you.gen & two \\
\hline liburu] & eta [Possp nire & hiru disko] & -ak] & desagertu & dira \\
\hline book & and I.gen & three & art & disappear & aux \\
\hline
\end{tabular}

In sum, we've got evidence for raising of both $S \& O$ genitives to a position higher than QP; given that Basque genitives are independent of the occurrence of a given D, I will assume that both genitives target the specifier of PossessivePhrase, as represented schematically in (19):

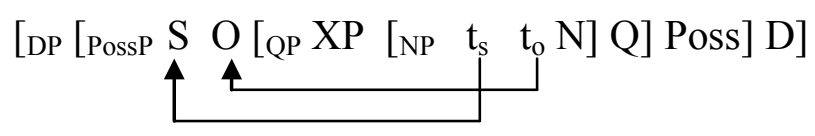

The proposal in (19) deserves some scrutiny: double genitives have been described in the literature, but they usually involve two different structural positions, one for each genitive (cf. English); in other languages, not only do double genitives involve two different forms but the higher structural position for genitives may also go hand-in-hand with N-raising to a functional projection (cf. Lindauer (1998) for German and De Wit (1997) for Dutch). The Basque situation differs in two respects: first, it seems as though both Basque subject and object genitives are entirely isomorphic and might target the same functional projection; second, the noun remains in situ as noun-adjective sequences show in (20):
a. zure [QP [spec bost] [NP+Adj erretratu txiki polit] $]$ hauek you.gen five portrait small pretty these 'These five beautiful small pictures $\{\mathrm{of} / \mathrm{by}\}$ you'
b. zure $[\mathrm{QP}[\mathrm{NP}+\mathrm{Adj}$

$$
\begin{array}{lllll}
\text { erretratu } & \text { txiki } & \text { polit] } & \text { [Q gutxi]] } & \text { hauek } \\
\text { portrait } & \text { small } & \text { pretty } & \text { few } & \text { these }
\end{array}
$$$$
\text { txiki polit] [Q gutxi]] }
$$
hauek

'These few beautiful small pictures $\{$ of/by $\}$ you'

Put it differently, the order $N$-Adj-Adj remains constant with respect to prenominal or postnominal quantifiers; this lack of N-raising in Basque squares well with the impoverished noun morphology given there is no number or gender concord inside noun phrases. 


\section{Xabier Artiagoitia}

\subsection{Arguments for a Multiple Specifier Approach}

The argumentation reduces to two types of facts: on one side, Richards' (2001) theory of multiple A-specifiers predicts the properties displayed by the combination of subject-object genitives; on the other side, a multiple specifier approach to genitives predicts the existence of Person Case Constraint effects in the case of two [+person] genitives, a prediction that turns out to be correct.

\subsubsection{Multiple A-specifiers and DP Internal Word Order in Basque}

The proposal advanced in section 2 presupposes a derivation like (19) for DPs with both subject and object genitives. We may assume, further, that the head possessive in Basque has a feature composition like the one in (21):

\section{(21) posssesive, (n-)ugenitive *, $u \varphi$-features (poss has no lexical content)}

where * means strong, and forces displacement of the relevant argument DPs. ${ }^{1} \mathrm{I}$ will leave aside whether the possibility of multiple genitive checking is due to a parametrized lexical property (Ura 1996) of a given functional head (possessive in the case at hand) or whether it has a different source (Boeckx 2003).

Basque multiple genitives are consistent with Richards' theory of multiple specifiers. He gives wide empirical evidence from both A- and A'-movement to establish that movement to multiple specifiers of a single head obeys superiority and, hence, systematically creates crossing paths. With respect to A-movement, he mentions superiority effects from the analysis of idiom chunks, A-scrambling in Japanese, object-shift in Germanic languages, multiple agreement systems, and so on.

Basque genitives, which represent A-raising of both subject and object to the same head, seem to provide additional support. Below I discuss (a) superiority and object-scrambling; (b) lack of scope ambiguity inside DPs; and (c) interaction of possessors with subject and object genitives.

Superiority. First of all, as predicted by Richards' theory, the resulting structure obeys superiority; the subject occupies the outer specifier and ccommands the object and the SO-X-N order is the unmarked and most usual one:

$\begin{array}{rlll}\text { Capa-ren } & \text { bere } & \text { buruaren }_{i} & \text { bost } \\ \text { gen his head.gen } & \mathrm{t}_{\mathrm{i}} \mathrm{t}_{\mathrm{j}} & \text { irudi]-ak } \\ \text { hive } & \text { fisO-X-N] } \\ \text { 'Capa's five pictures of himself' } & & \text { picture.art }\end{array}$

\footnotetext{
${ }^{1}$ The displacement property may be due to an EPP-feature of possessive, à la Chomsky (2001).
} 


\section{Basque Genitive Case and Multiple Checking}

As pointed out by Eguzkitza (1993), it is true that Basque allows [OS...N] word orders. But these seem to be derived by further moving the object to the left of the subject, a movement which has the effect of giving what is left behind it a highly restrictive reading, absent in the neutral word order. Eguzkitza's own examples and interpretations are given in (23):
a. Cortazar-en Poe-ren itzulpena
.gen .gen translation.art
'Cortazar's translation of Poe'
b. Poe-ren ${ }_{\mathrm{i}}$ Cortazar-en $\mathrm{t}_{\mathrm{i}}$ itzulpena (Eguzkitza 1993: 170) 'out of all Poe's translations, [we pick] CORTAZAR'S translation'

Eguzkitza derived examples like (23b) via A'-topicalization to the [spec, D] position, an account that seems questionable. That [OS...N] orders are derived via subsequent object-scrambling is shown by two pieces of data: first, object anaphors cannot scramble around a genitive subject, as one can observe by comparing (22) to the ungrammatical (24):

$$
\text { *[Bere buruaren } \left.{ }_{\mathrm{i}} \text { Capa-ren } \mathrm{t}_{\mathrm{i}} \text { bost irudiak }\right] \ldots \quad\left[={ }^{*} \mathrm{O}_{\text {anaphor }}-\mathrm{S}-\mathrm{X}-\mathrm{N}\right]
$$

Second, a universal quantifier in subject position can bind a pronoun variable in SON orders, whereas the reverse is impossible; however, a (DP-internally) scrambled object with a universal quantifier can bind a pronoun variable in subject position $(=25 \mathrm{c})$ :

$$
\begin{aligned}
& \text { a. [idazle bakoitzaren }{ }_{i} \text { bere }_{i} \text { poema baten bi bertsio] } \\
& \text { writer each.gen his poem one.gn two version } \\
& \text { daude liburuan } \\
& \text { are book.loc } \\
& \text { 'In the book there are two versions of one of his poems by every writer' } \\
& \begin{array}{ccclc}
\text { b. }{ }^{*}\left[\text { Bere }_{\mathrm{i}}\right. & \text { idazlearen } & \text { poema bakoitzaren } & \text { bi } & \text { bertsio } \\
\text { its } & \text { writer.gen } & \text { poem each.gen } & \text { two } & \text { version }
\end{array}
\end{aligned}
$$

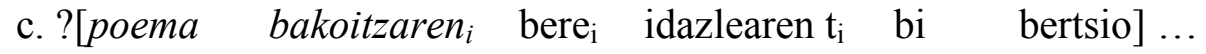

$$
\begin{aligned}
& \text { poem each.gen its writer.gen two version.art } \\
& \text { 'In the book there two versions of one of his poems by every writer' }
\end{aligned}
$$

$$
\text { a. } \sqrt{\text { Subj- } \forall \text { Obj-vbl b. }} \text { Subj-vbl Obj- } \forall \text { c. } \sqrt{\text { Obj- } \forall \text { Subj-vbl tobj }}
$$

The movement of the object doesn't give rise to WCO effects in (25c), thus confirming that it is not A'-movement. In sum, the data in (24-25) show that object-movement is closer to A-scrambling than it is to A'-scrambling and they also suggest the object's usual position is to the right of the subject. Thus, 


\section{Xabier Artiagoitia}

[OS...N] orders result from at least two movements/attractors: raising of both subject and object past QP and subsequent object-scrambling.

Lack of scope ambiguity inside DP. According to Richards (2001), a related property of multiple A-scrambling in Japanese is that no quantifier ambiguities arise; in other words, multiple specifiers of the same head tend to reflect the same scope relations as in the base position. Basque allows very few cases of reverse scope but, in cases where this is possible in sentential subject-object scope interactions, virtually all speakers interpret the genitive subject as taking scope over the genitive object. This is illustrated in the contrast in (27):

(27) a. Ume guztiek ipuin bi kontatu dituzte $(2>\forall, \forall>2)$

'All children told two fairy tales'

b. Ume guztien ipuin biren kontaketa ikusi dugu $(\forall>2, *$ ? $2>\forall)$

'We witnessed all children's telling of two fairy tales'

Possessor arguments and Superiority. Richards' theory can also give us a clue to understand some data from Eguzkitza (1993). This author regarded possessorsubject-object patterns (=28a) as grammatical but possessor-object-subject orders $(=28 \mathrm{~b})$ as ungrammatical:
a. [DPMonzonen
Leizarragaren Bibliaren
itzulpen-a]
.gen
.gen Bible.gen
translation.art
b. * [DP Monzonen
Bibliaren
Leizarragaren itzulpen-a]
.gen
Bible.gen
.gen translation.art
'Monzon's (copy of the) translation of the Bible by Leizarraga'

Eguzkitza's account was formulated in terms of competition between $\mathrm{P}$ and $\mathrm{O}$ for the [spec, D'] position. However, Richards' approach suggests a more attractive analysis. If, as now standardly assumed by many, the possessor argument also originates inside NP (or a related projection) and c-commands both subject and object arguments, Richards' theory of multiple specifiers predicts that, if all the possessor, subject and object arguments are attracted to Possessive, their paths will cross and the resulting word order will be possessor-subject-object. This prediction is correct, as just seen, given that (28a) is the unmarked and default order. The derivation would then be something like (29):

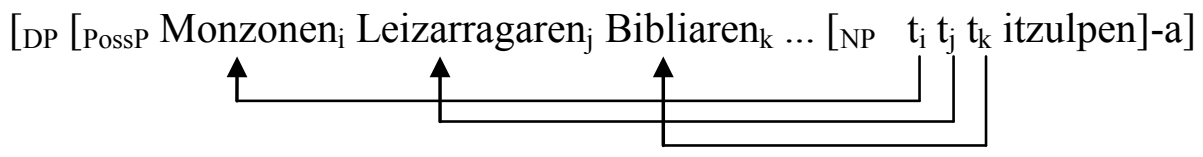

The ungrammatical $* P-O-S$ order is simply the result of the moved arguments not respecting superiority. 


\title{
Basque Genitive Case and Multiple Checking
}

\subsubsection{PCC Effects as Evidence for Multiple Checking}

The proposal made so far makes an interesting prediction: assuming that Jeong's version of $\mathrm{PCC}$ is right, if both $\mathrm{S}$ and $\mathrm{O}$ genitives raise to the same functional projection, we predict Person Case Constraint effects given that the same feature (i.e. person) cannot be checked twice. As expected, the PCC issue never arises when two DPs check their features in different projections (=30a) but is at stake in some well-known cases $(=30 \mathrm{~b})$ :

\author{
(30) a. nik zu ikusi zaitut \\ I.E you see 2A.R.1E \\ 'I saw you' \\ b. *Zuk ni etsaiari saldu naiozu \\ You.E I.A enemy.D sell 1A.R.3D.2E \\ 'You sold me to the enemy' (Ormazabal \& Romero 2007: 316)
}

In examples like (30a), no conflict arises given the standard assumption that subjects and objects check their case and $\phi$-features against different functional heads (T and v); examples like (30b), on the other hand, are usually referred to as violations of Bonet's Person-Case Constraint:

(31) Person-Case Constraint

if DATIVE, then ACC $/ \mathrm{ABS}=3^{\text {rd }}$ person (Bonet 1994: 36)

This constraint is under scrutiny in current theory: Ormazabal and Romero (2007) have convincingly shown that the constraint is basically syntactic in nature, independent of case and morphological realization, and propose to derive it from the impossibility of having two animate objects agreeing with the verbal complex. Since we don't deal with object agreement proper but with a configuration where subject and object check the same feature, more abstract approaches seem relevant: Boeckx (2003) and, specially, Jeong (2004) argue that in situations of multiple feature checking, multiple case checking is licit given that case is an uninterpretable feature on the goal (and can be checked in a symmetric way); multiple person checking is, however, illicit since it is only interpretable on the goal and dependent on asymmetric checking (closest ccommand) which can only take place once. As a result, as Jeong puts it, there cannot be two [+person] or [+animate] DPs in the same domain:

(32) General PCC

Two DPs cannot be $[+$ person] $/[+$ animate $]$ if they check that feature against the same functional head (T/v) (Jeong 2004: 419). 


\section{Xabier Artiagoitia}

In a similar vein, Rezac (2008) argues that PCC effects arise when the same probe establish a person-Agree relationship with two goals: the first one blocks person agreement with the one, provided the first one c-commands the other.

Going back to (30b), and taking for granted with Jeong (2004: 418) that person entails animacy and lack of animacy entails lack of person (i.e. [+person] $\rightarrow$ [+animacy]; [-animacy] $\rightarrow$ [-person]) the only assumption one needs to explain its ungrammatical status is that agreeing datives are inherently marked as [+animate] in Basque, ${ }^{2}$ even when they are $3^{\text {rd }}$ person. In other words, we have two DPs, one [+person] and the other [+animate], checking their features against the same functional head $v$. There is no violation of the General PCC if the offending dative has no agreement marker in the auxiliary (and behaves as a plain PP):

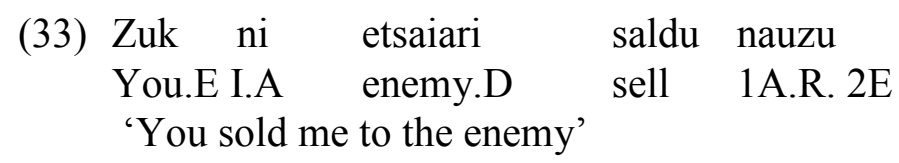

On general grounds, we don't expect the PCC to be an issue in the case of two genitives being realized in different domains and agreeing with different probes/heads. This would be the case of English or Spanish genitives in (34):

(34) a. My \{description, portrait, vision, examination \} of you

b. Tu \{descripción, necesidad, retrato\} de mí (Spanish)

'Your \{description, necessity, portrait\} of me'

The higher genitive is generally associated with a functional projection (possessive), whereas the lower genitive is associated with a lower head ( $\mathrm{N}$ or $n$ ). However, in the case of Basque, given that both subject and object genitives are in the specifier of the same functional projection possessive, the prediction is that both DPs cannot be [+person]. A good test is given by first and second person arguments, which I assume are necessarily [+person]. The ungrammaticality of the examples (35c and 35d) confirm that the proposal is correct:

${ }^{2}$ There is good evidence for this, given that locative inanimate goals cannot appear as datives in ditransitive structures (Oyharçabal 2010):

(i)

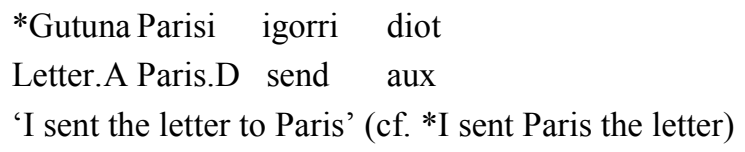

Ormazabal and Romero (2007) also assume that agreeing datives are inherently animate. 


\section{Basque Genitive Case and Multiple Checking}

(35) a. nire Jonen (hiru) erretratuak

I.gen .gen three portrait.art

'My (three) pictures of John'

b. Jonen nire (hiru) deskribapenak

.gen I.gen three description.art

'John's (three) descriptions of me'

c. *nire zure (hiru) erretratuak

I.gen you.gen three portrait.art

'My (three) pictures of you'

d. *zure nire (hiru) deskribapenak

you.gen I.gen three description.art

'Your (three) descriptions of me'

I outline the ungrammatical derivation in (36), where the head Poss cannot person-agree with a [+person] object if there is a closer c-commanding [+person] subject:

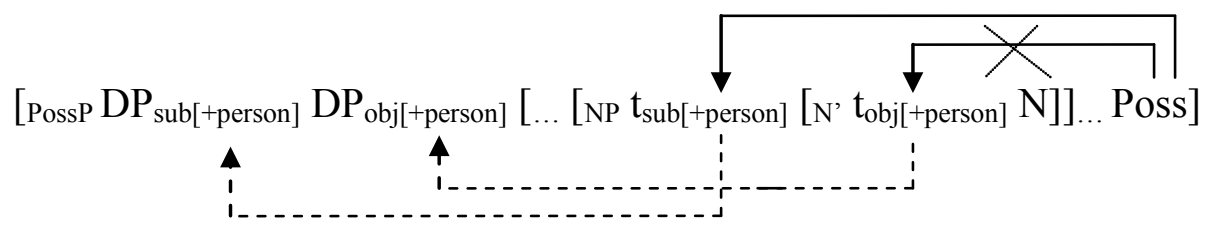

In short: examples combining first or second person and third person [-person] subject/object genitives are at best slightly unusual given the general oddity of Basque double genitives, but the combination of first and second person arguments (both [+person]) is sharply ungrammatical, which suggests that both genitive DPs are checking their person features against the same functional head (i.e. possessive).

Three conclusions can be drawn from the proposal in this article: (a) it suggests that UG allows the existence of heads whose case feature can be checked n-times, but $\varphi$-features can only be checked once (as argued by Jeong 2004); (b) interestingly, the head possessive has all the said properties despite having no morphological realization, which favors a syntactic approach to PCC phenomena; and (c) Basque also seems to personify a situation where raising of genitive DPs is pervasive: all DPs can, and must, raise to the specifier of Possessive.

\section{References}

Alexiadou, Artemis, Liliane Haegeman and Melita Stavrou. 2007. Noun Phrase in the Generative Perspective. Berlin: Mouton de Gruyter. 
Artiagoitia, Xabier. 2002. The functional structure of the Basque noun phrase. In X. Artiagoitia, P. Goenaga \& J. A. Lakarra, eds., Erramu Boneta: Festschrift for Rudolf P. G. de Rijk, 73-90, Bilbao: Supplements of ASJU.

Artiagoitia, Xabier. 2006. Euskarazko izen-sintagma: arkitektura eta egitura funtzionala. University of the Basque Professorship Report.

Boeckx, Cedric. 2003. Symmetries and asymmetries in multiple feature checking. In C. Boeckx and K. K. Grohman, eds., Multiple Wh-Fronting, 17-26, Amsterdam: John Benjamins.

Bonet, Eulalia. 1994. The Person-Case Constraint: A Morphological Approach. In H. Harley and C. Phillips, eds., The Morphology-Syntax Connection. MIT Working Papers in Linguistics 22, 33-52, Cambridge MA: MITWPL.

Chomsky, Noam. 2001. Derivation by Phase. In M. Kenstowicz, ed., Ken Hale: $A$ life in language, 1-50, Cambridge MA: MIT Press.

Delsing, Lars-Olof. 1998. Possession in Germanic. In A. Alexiadou and C. Wilder, eds., Possesors, Predicates and Movement in the Determiner Phrase, 87-108, Amsterdam: John Benjamins.

Eguzkitza, Andolin. 1993. Adnominals in the Grammar of Basque. In J. I. Hualde and J. Ortiz de Urbina, eds., Generative Studies in Basque Linguistics, 163-187, Amsterdam: John Benjamins.

Goenaga, Patxi. 2003. - EN eta $-K O$ atzizkiez berriro. In J. M. Makatzaga and B. Oyharçabal, eds., Euskal Gramatikari eta literaturi buruzko ikerketak XXI. Mendearen atarian. Iker 14 (1), 279-303, Bilbao: Euskaltzaindia.

Jeong, Youngmi. 2004. Asymmetries in Multiple Case Assignment. In V. Chand, A. Kelleher, A. J. Rodríguez, and B. Schmeiser, eds., Proceedings of the 23rd West Coast Conference on Formal Linguistics, 413-421, Somerville MA: Cascadilla Press.

Lindauer, Thomas. 1998. Attributive Genitive Constructions in German. In A. Alexiadou and C. Wilder, eds., Possesors, Predicates and Movement in the Determiner Phrase, 109-140, Amsterdam: John Benjamins.

Longobardi, Giuseppe. 2001. The structure of DPs: some Principles, Parameters and Problems. In C. Collins and M. Baltin, eds., The Handbook of Contemporary Syntactic Theory, 562-601, Oxford: Blackwell. 


\section{Basque Genitive Case and Multiple Checking}

Ormazabal, Javier and Juan Romero. 2007. The Object Agreement Constraint. Natural Language and Linguistic Theory 25: 315-347.

Oyharçabal, Bernard. 2010. Basque ditransitives. In M. Duguine, S. Huidobro and N. Madariaga, eds., Argument Structure and Syntactic Relations: A crosslinguistic perspective, 233-260, Amsterdam: John Benjamins.

Picallo, Carme. 1991. Nominals and nominalizations in Catalan. Probus 3: 279316.

Rezac, Milan. 2008. The syntax of eccentric agreement: the Person Case Constraint and absolutive displacement in Basque. Natural Language and Linguistic Theory 26: 61-106.

Richards, Norvin. 2001. Movement in Language. Interactions and Architectures, Oxford: Oxford University Press.

Schoorlemmer, Maaike. 1998. Possessors, articles, and definiteness. In A. Alexiadou and C. Wilder, eds., Possesors, Predicates and Movement in the Determiner Phrase, 55-86, Amsterdam: John Benjamins.

Szabolcsi, Anna. 1994. The Noun Phrase. In F. Kiefer and K. E. Kiss, eds., The Syntactic Structure of Hungarian. Syntax and Semantics 27, 179-274, New York: Academic Press.

Ura, Hiroyuki. 1996. Multiple Feature-Checking: A Theory of Grammatical Function Splitting. MIT PhD dissertation.

Wit, de Petra. 1997. Genitive Case and Genitive Constructions, University of Utrecht $\mathrm{PhD}$ dissertation.

Zabala, Igone. 1999. Izen-sintagma konplexuak: adjektiboen eta izenlagunen segidak. In J. C. Odriozola, ed., Zenbait gai euskara teknikoaren inguruan, 107157, Bilbao: UPV/EHU.

Xabier Artiagoitia

Universidad del País Vasco / Euskal Herriko Unibertsitatea

Department of Linguistics and Basque Studies

Faculty of Letters

Unibertsitatearen Ibilbidea 5

01006 Vitoria-Gasteiz

xabier.artiagoitia@ehu.es 